\title{
Rearticulating Diplomatic Relationships: \\ Contextualizing Tuvalu-Taiwan Relations
}

Jess Marinaccio

\begin{abstract}
$\mathrm{D}$ iplomatic competition between Taiwan, or the Republic of China (ROC), and the People's Republic of China (PRC) is now a common topic in research on the so-called developing world (Hu 20I5; Yang 20II). For example, in recent discussions on the rise of China in the Pacific, scholars have advanced de-powering and empowering narratives in which either Taiwan-PRC infighting drives diplomatic action and the Pacific has little agency (see D’Arcy 20I6) or Pacific nations are subjective agents that choose Taiwan or the PRC according to their preference (see WesleySmith and Porter 20I0). A common theme in both analytical frameworks is a failure to acknowledge that Pacific-Taiwan-PRC relationships have always involved issues removed from Taiwan-PRC competition and as a result entail levels of complexity that are often overlooked. Thus, contextualizing these relationships reveals "entangled and intimate histories" that contest a static, one-dimensional view of Pacific-Asia diplomacy (Salesa 2016, I23).

Tuvalu is currently one of six Pacific nations (ie, Tuvalu, Kiribati, the Marshall Islands, Palau, Solomon Islands, and Nauru) that maintain formal relations with Taiwan. Yet in scholarship on Taiwan, Tuvalu is typically discussed as merely one of Taiwan's limited number of allies (Hu 20I5; Yang 20II), and even volumes examining Pacific-Taiwan-PRC diplomacy have neglected Tuvalu (see Wesley-Smith and Porter 2010). In research on Tuvalu, Taiwan and diplomacy are rarely emphasized, and recent scholarship has focused predominantly on climate change (see Goldsmith 20I6). Consequently, in this article, I analyze official (ie, government) discourse from the Tuvalu-Taiwan relationship to address this research gap and show how this discourse has consistently structured and
\end{abstract}

The Contemporary Pacific, Volume 3I, Number 2, 448-475

(C) 2019 by University of Hawai'i Press

448 
reflected the nuanced and dynamic histories inherent in Tuvalu-Taiwan relations.

\section{A Historical Background for Tuvalu-Taiwan Diplomacy}

Tuvalu and Taiwan formally established diplomatic relations on I9 September I979 (UDN 1979). At that time, Tuvalu had recently become postcolonial, having declared independence on I October 1978 after separating from Kiribati, to which it had been linked as part of Great Britain's Gilbert and Ellice Islands Colony (Goldsmith 20I2, I29). However, because it possessed historical or linguistic ties to Nauru, Kiribati, Tonga, Sāmoa, Banaba, and Fiji, Tuvalu was by no means an isolated player in the Pacific region after gaining independence (Beaulieu 2009; Lawson I989; Noricks I98I; K Teaiwa 2004). Furthermore, in the I970s, there was a growing assertion both internationally and in Tuvalu of rights to Exclusive Economic Zones (EEZs), which demarcated control of national marine resources (TNS I979d, I979e). Though Tuvalu did not emerge from colonization with everything it had hoped for from the British (Goldsmith 2OI2), it did control extensive marine assets that many nations, especially the archipelagic and peninsular countries of East Asia, desperately hoped to access.

For its part, in I979, Taiwan was nearing the end of a martial law period that began in 1949 with the retreat of Nationalist, or Kuomintang (кмт), forces from mainland China to Taiwan after their loss to Communist forces in the Chinese Civil War (Corcuff 2000). This era was preceded by a fifty-year period of Japanese colonization on Taiwan that ended with the conclusion of World War II, and scholars have suggested that the KMT retreat marked the transition from one period of colonial rule to another for Taiwan's majority population (ie, Han Chinese who left the mainland beginning in the I600s) (Muyard 2015, 24). This retreat also signaled Taiwan's continued status as a settler colony vis-à-vis the archipelago's indigenous peoples (Shih 2016). Furthermore, in I979, Taiwan was reeling after withdrawing from the United Nations (UN) in I97I and subsequently severing official ties with Japan and the United States. In this period, numerous countries established relations with the PRC, asserting that Taiwan belonged to that nation-state (Chu 201 5, 707; Gao I980).

It was in this context that in March I979 Tuvalu's government newspaper, Tuvalu News Sheet (TNS), printed an article titled "Tuvalu's Asian Diplomacy," which highlights the rapid development of Tuvalu's relation- 
ships with East Asian nations like Taiwan shortly after independence (TNS I979a). Contemporaneously, the Taiwan government began reporting on early diplomatic forays into Pacific nations, including Tuvalu. These newspaper and government reports are frequently characterized by a narrative style that suggests the complexities of Pacific-Asia relationships at the time and provide a foundation from which more recent discourse on TuvaluTaiwan relations can be temporally contextualized and complicated.

Given this background, I begin by outlining the Pacific studies rationale and methods structuring this article. Subsequently, I examine official Tuvaluan and Taiwanese narratives from the I970s and I980s to demonstrate how early diplomacy was determined not by official maneuvering but by preexisting "trans-local" and individual connections and conflicts (Matsuda 20I 2, 5). Next, in analyzing Tuvaluan and Taiwanese leadership statements from 2000 to the present, I show how diplomatic rhetoric has become more formalized and sketch how, more recently, Tuvalu and Taiwan have used each other to shape and fortify their national identities. However, I also highlight connections to earlier narratives, especially consistent tension in Tuvaluan discourse due to fisheries conflicts with Taiwan and continued preoccupation in Taiwanese discourse regarding whether Taiwan is superior to Tuvalu. In the conclusion, I illustrate how articulations between early narratives and more recent discourse foreground Tuvaluan and Pacific agency and show that Tuvalu-Taiwan relations have always both included and exceeded Taiwan-PRC competition.

Before moving forward, it is important to note that, due to archival gaps, official Taiwanese reports on diplomatic missions to Tuvalu do not appear after the late I980s, while full-length leadership statements on Tuvalu are not available in paper or online collections until 2000. Additionally, archive holdings for state-run newspaper are incomplete after I992, and a critical mass of leadership statements only emerged after Tuvalu joined the United Nations in 2000. Hence, the I990s are deliberately excluded from analysis in this paper. However, thematic connections between the I970s-1980s and 2000 to the present suggest that these periods are not wholly separate but are instead distinguished by shifts from trans-local and often informal discourse in the r970s and I980s to formalized diplomatic rhetoric more recently. News coverage from Tuvalu, which is available from 1976 to I992, verifies this transition because, after the first visit by a Tuvaluan head of government to Taiwan in late I986, Tuvalu's discourse transitioned in tone from narrative and informal to formal (Tuvalu Echoes I986a, I9866; UDN I986). 


\section{A Pacific Studies Rationale, Articulation Theory, and Discourse Analysis}

Although Teresia Teaiwa identified the origins of Pacific studies in "amateur ethnographies from ... the seventeenth century [and] orientalisttype scholarship" (200I, 348), Pacific studies traces its main roots to World War II, the Cold War, and the development of pragmatic interest in Pacific nations by Pacific Rim countries like the United States and Australia (Wesley-Smith I995). However, with the end of the Cold War and intellectual challenges from postcolonialism, postmodernism, and cultural studies, Pacific studies has been required to demonstrate increased reflexivity and a "coherent conceptual basis" (Goss and Wesley-Smith 20IO, xiv-xv). Given this complex history, Terence Wesley-Smith identified three rationales possibly motivating research on the Pacific: the "laboratory rationale," which "values the Pacific Islands and Pacific Islanders primarily as objects for study"; the "pragmatic rationale" embodied in "the need to know about the Pacific Islands places with which ... metropolitan countries have to deal"; and the "empowerment rationale," which is "more firmly grounded in indigenous experience" and aims to "incorporate multiple voices into ... narratives" (I995, I 28; 20I6, I 57-I 59). ${ }^{1}$

Wesley-Smith noted that the "pragmatic rationale for Pacific studies has, no doubt, received a boost as a result of the rise of China in Oceania" (2016, I 57), and recent works on the PRC in the Pacific (which inevitably include Taiwan) are often couched in the pragmatic language of strategic studies, as mentioned in the introduction. However, the empowerment rationale is also currently a major trajectory in Pacific studies, and in this paper, I focus on empowerment rather than pragmatism to evaluate Tuvalu-Taiwan relations from an alternative perspective, whereby discourse emerging from both locations can be valued as equally legitimate and important.

From a conceptual and methodological perspective, an empowermentoriented Pacific studies emphasizes interdisciplinarity, comparativity, and indigenous epistemologies while also adopting indigenous frameworks, multi-sited ethnography, and articulation as key methods (K Teaiwa 20I4, 68; T Teaiwa 20I0, 20I7a). Because articulation theory is a flexible tool that accommodates complex pasts, presents, and futures while also providing the strategic potential to unsettle static ideas of society, politics, and culture, I adopt articulation as the main analytical mode in this article. 
Articulation theory was developed in cultural studies as a response to reductionism in Marxism, in which "every element in society ... [was] reduced to ... the operations of the corresponding mode of production" (Slack 1996, I I6). Articulation is thus "a way of thinking the structures of what we know as a play of ... fragments" (Slack I996, II2), and it has been defined in Pacific contexts as "the sense that any socio-cultural ensemble that presents itself to us as a whole is actually a set of historical connections and disconnections" (Clifford 2003, 45). Teresia Teaiwa additionally stressed that applying articulation theory to Pacific histories "[provides] layers upon layers of contextualization [and] more accurately [represents] cultural and political complexity" (2005, 204). Consequently, I use articulation to frame Tuvalu-Taiwan diplomacy not as a unified whole but instead as an ensemble of contextually specific elements that connect and disconnect as they interact with dynamic historical, cultural, and political backgrounds.

Furthermore, because discourse, which is "an ensemble of ideas, concepts and categories through which meaning is given to social and physical phenomena" (Hajer and Versteeg 2005, I75), is uniquely linked to an articulated view of society, I combine discourse analysis, or the study of "what talk is doing and achieving" (Wood and Kroger 2000, 5), with articulation. This integration demonstrates how juxtaposing bodies of talk illuminates shifting yet integrated characterizations of Tuvalu, Taiwan, and their relationship over time.

Building on this framework, in the remainder of this article, I first outline official Tuvaluan and Taiwanese discourse from the I970s and I980s. Subsequently, I analyze Tuvaluan and Taiwanese leadership statements from 2000 to the present, highlighting how elements in the two periods have continuously articulated and disarticulated.

\section{Narrativizing Tuvalu-Taiwan Relations- I970S TO I 980 S}

Official reporting from the beginnings of Tuvalu-Taiwan relations in the I970s and I980s, which coincided with Tuvalu's debut in international diplomatic circles and early Taiwan-government forays into the Pacific, is much less rigidly structured than current discourse on international affairs. Because no solidified understandings of Tuvalu-Taiwan diplomacy existed at the time, discourse in Tuvalu's state-run newspaper and Taiwan-government reports frequently adopted a narrative mode, using storytelling 
to conceptualize incipient relationships. This discourse evinces how early Tuvalu-Taiwan diplomacy (and Pacific-Asia diplomacy more broadly) was characterized by "multiple sites of trans-localism, [or] the specific linked places where direct engagements took place" (Matsuda 20I2, 5). Both the narrative style adopted in early discourse and trans-localism are illustrated in the following subsections, which focus first on Tuvalu and then on Taiwan.

\section{Tuvalu: Taiwanese "Drama on the High Seas"}

Shortly after Tuvalu's independence in 1978, reporting on diplomatic relations between Tuvalu and Asia-specifically South Korea, Japan, and Taiwan-was a feature of Tuvalu News Sheet, a periodical published from I976 to 1983 through Tuvalu's Broadcasting and Information Division (Goldsmith 2016; TNS 1978, I979a, I979b, I979f). The rapid development of Tuvalu-Asia relationships was, in many instances, based on the need for East Asian nations to purchase fishing licenses so that vessels operated by their citizens could legally access Tuvalu's sea territory. For example, one article in Tuvalu News Sheet notes that immediately after Tuvalu and Japan established diplomatic relations, "the Second Secretary in the Japanese Embassy at Suva . . . and the Assistant Manager of the Federation of Japan Tuna Fisheries Cooperative Association" arrived in Tuvalu's capital, Funafuti, to negotiate a fisheries licensing agreement (TNS I979b; for South Korea, see TNS I979c).

Although these accounts accord with current analysis of Asian diplomacy in the Pacific that centers on fisheries (Aqorau 2015, 223; Izumi 2010, 89-90), TNS reporting also suggests that it was not Asian governments who were catalysts in establishing relations with Tuvalu. Rather, it was interaction between the Tuvalu government and Asian fishing interests-which were often located in other Pacific places (typically American Sāmoa) — that required intervention by Asian governments (see LYG I975, 6; TNS I979e). This challenges assumptions of unified national action in diplomacy, as Asian governments were often called on to intervene in situations in which they were not directly involved. It also highlights the trans-local nature of Pacific histories in which direct engagement between sites like Tuvalu and American Sāmoa forged connections between the governments of Tuvalu, Taiwan, Japan, and South Korea.

In Tuvalu News Sheet, this phenomenon was the subject of extensive narrativization, especially in articles on Taiwanese fishing vessels, where Taiwanese fishing transgressions and Tuvaluan skill in detecting 
transgressions were serialized over several issues. These narratives, two of which I outline below, foreground the trans-local character of early Tuvalu-Taiwan interactions, as well as Tuvaluan agency. However, at the time, they also served a nationalizing agenda, underscoring Tuvalu's unified action in the face of wayward Taiwanese fishing crews.

First, from 3 August to 3 I October 1979, Tuvalu News Sheet printed at least five articles referencing the case of the Chyan Yeng No 2 I, a Taiwanese fishing vessel based in Pago Pago, American Sāmoa, and contracted to Feng Ch'un Agents, which represented the US firm Starkist. The vessel was charged with fishing without a license inside the 200-mile economic resources zone of three Tuvaluan islands (Nanumaga, Vaitupu, and Funafuti), the ship's captain was arrested, and the vessel was fined $\mathrm{A} \$ 20,000$ (approximately us $\$ 22,548$ at the time). The ship, crew, and captain were detained on Funafuti for five weeks before fines were finally paid and they were released (TNS I979d, I979e).

Tuvalu News Sheet's retelling of the capture of the Chyan Yeng and the expertise of Tuvaluan authorities in discovering foul play not only highlights Tuvalu's agency and Taiwan's naivete in its illegal exploits but also depicts a united Tuvaluan nation-state:

The vessel called at the capital-Funafuti-on late afternoon Monday July I 6 with what was reported to be engine trouble and water shortage.... The following afternoon, the police boarded the vessel and arrested the captain.... Investigations prompted by the Attorney General and carried out by police, customs and fisheries officials, revealed that the ship was carrying 25 tons of fish, a portion of which was fresh and un-frozen. It was suspected that some of this fish may have been taken from Tuvalu waters, since Captain Shing has admitted to fishing about 70 miles off-shore from Nanumanga. He claims, however, that he believed the 200 mile economic resources zone to apply only to waters surrounding Funafuti. Nevertheless, it was reported that the vessel called at Vaitupu, which is within 200 miles of the capital, the previous week and it is believed that fish may also have been taken from waters near the island. (TNS I979d)

Additional articles on the incident highlight a lack of rapid Taiwan-government response to transgressions, and Tuvalu's Secretary for Commerce and Natural Resources Feue Tipu is reported as proclaiming that "such problems could be avoided by the local issuance of fishing licenses, provided that foreign nations [were] cooperative in securing licensing agreements with Government." Tipu further warned that "[foreign govern- 
ments] ... might want to better look after their interests by encouraging the institution of formal licensing agreements" (TNS I979e). Interestingly, the issue of slow response to fishing crises was also integral to Taiwangovernment reports from the period (discussed in the next subsection), demonstrating a point of consonance in early Tuvaluan and Taiwanese discourse.

A second and more dramatic incident is described in "Drama on the High Seas-Taiwanese Boat Escapes," which was published on 23 January 1980 , with a related article printed on 20 February of the same year (TNS I980a, I980b). These articles recount the tale of the Taiwanese fishing vessel Tong Chou Kao Hsiung No 7 (also originating from American Sāmoa), which "appeared" and "disappeared" near the coast of the central Tuvaluan island Nukufetau. During this time, the ship's crew requested supplies, and it was noted that fish on the vessel were "still fresh." This led to a nationwide search for the ship involving even "a Fijian cargo boat [the mV Ai Sokula] running on a British Phosphate Commissioners' charter to repatriate Tuvalu employees from Banaba." The Ai Sokula spotted the Taiwanese vessel fishing near one of Tuvalu's northern islands, Niutao, at which point "the Government issued instructions for her arrest," and the ship's captain "stole off in the middle of the night," beginning "the country's first troublesome scene at sea." The story unfolds as follows:

[The] Ai Sokula reported back that she had come alongside the Taiwanese vessel, but although the Ai Sokula had put 2 men on board the vessel her master refused to comply with the instructions to head for Funafuti.

The Government then instructed the Nivaga to leave as soon as possible to rendezvous with the Ai Sokula ..., with instructions to escort the Taiwanese boat to Funafuti. ... The following morning however, ... the fishing vessel was nowhere in sight. It is believed that about midnight, the previous evening, the master of the boat hauled in his nets and extinguished his lights before sailing away from the Ai Sokula which had been trying to detain her. ... Following this incident ... the Government is preparing to take legal action against [the Tong Chou's] master on several charges. (TNS I980a)

As with reporting on the Chyan Yeng, this narrativizing of "drama on the high seas" underscores Tuvalu's agency in its ability to rally forces and track the Tong Chou, as well as Taiwanese folly in stopping for supplies at an island near which the Tong Chou was fishing illegally.

Reporting on this incident also clearly demonstrates the trans-local links characterizing Tuvalu-Taiwan encounters shortly after Tuvalu's 
independence. In both narratives, private Taiwanese fishing vessels based in American Sāmoa and connected to the United States are involved in direct conflict with Tuvaluan officials or citizens who then call on the Taiwan government to resolve the issue through the purchase of fishing licenses. However, in the case of the Tong Chou, more extensive links and engagements are suggested when a Fijian boat carrying Tuvaluan citizens employed in British mines in Banaba is enlisted in Tuvalu's search for the boat. In this way, myriad locations and histories are entangled within a single high-seas pursuit, providing a tangible example of Katerina Teaiwa's observation that Pacific histories involve the "movement of all kinds of bodies and materials" (2004, 220; see also Dvorak 2014, 352).

Yet we also see how early discourse on illegal Taiwanese fishing in and around Tuvalu, as well as the need to assert and define the extent of Tuvalu's Exclusive Economic Zone, served to naturalize Tuvalu's identity as a nation-state, given that in each narrative, a series of Tuvaluan islands were articulated through common violations by the Taiwanese. This indicates how trans-local relationships and conflicts could be used to solidify national identity, foreshadowing how official Tuvaluan discourse functions today.

\section{Taiwan: Our Expatriates in the South Pacific}

For Taiwan, at least two records of oral hearings in which Taiwan's Ministry of Foreign Affairs discussed Pacific diplomacy at the Taiwan Legislature are available for the I970s and I980s, specifically records for 1974 and 1988. The 1974 report, which describes the first official Taiwanese delegation to the Pacific (LYG I975, 6), does not mention Tuvalu, focusing instead on Sāmoa, Tonga, Fiji, and Papua New Guinea. However, this report dovetails with TNS articles and also shows how the Taiwan government at the time was fixated on stories of Chinese or Taiwanese expatriates (僑胞) in the Pacific. ${ }^{2}$ This underscores the importance of individual experiences to government discourse on Pacific-Taiwan relations. Much of this storytelling demonstrates official concern regarding whether expatriate loyalties were aligned with Taiwan or the PRC (see Heylen 20I0, I6-I 8; Shih 20I I, 7IO), which seemingly confirms international-relations research in which Taiwan's Pacific strategy is based on competition with the PRC (Topo 20I4, 54). However, this storytelling also shows how, with the rise of nation-states in the Pacific-Asia region, governments were often scrambling to overtake or accommodate trans-local engagements already initiated by individual citizens or business interests (see also Smith 
20I2). With this in mind, before analyzing the I 988 record, which directly addresses Tuvalu, I first consider the 1974 report.

First, in the 1974 report, the problem of illegal fishing so dramatically outlined in Tuvalu News Sheet is also clearly explicated. For instance, Taiwan's deputy minister of foreign affairs explained that two hundred Taiwanese fishing vessels were operating in American Sāmoa, bemoaning the complexities of fisheries regulations:

Especially now that many countries have expanded their sea territories, we must remember that ... it is easy for fishermen to cross into [these] territories when they are not paying attention. . . . [It] might be that some fishermen don't know that the sea territories of various countries have expanded.... [We] must make them pay attention to this. If we wait until they are detained or [items] confiscated, the losses are great. Whether to guarantee government rights or fishermen interests, we must take active measures.... [Our] reactions have been slow. (LYG I975, 6-7, I3 $)^{3}$

This explanation underscores a gap between Taiwanese fishermen in American Sāmoa and their government representation while also suggesting how major changes in international policy during this period were far removed from the people most in danger of violating relevant regulations.

The 1974 report is also notably characterized by tales of Chinese or Taiwanese expatriates in locations visited by the Ministry of Foreign Affairs, and, frequently, the success of even one expatriate is taken as indicative of a favorable atmosphere for foreign relations. For example, the deputy minister related that in Sāmoa "all important economic activities are undertaken by the Chinese." He also explained that "there is one expatriate, Mr Chen," who arranged a welcome party for the Taiwanese delegation that was attended by all local ministers because "every week [Mr Chen] invites the local people to watch a free movie at his home; everyone knows [him]" (LYG I 975, 7-8). The deputy minister further surmised that "Fiji is friendly to [Taiwan]" because "Chinese expatriates have contributed to the Fiji economy" (LYG I975, 8). He reported:

Our expatriates are quite influential. I didn't know ... that the [Fijian] Prime Minister ... wouldn't have time to meet with me [during my visit]. ... I discussed this with an expatriate. He . . called straight over and arranged for a meeting the next day. (LYG I975, 9)

The Taiwan government's use of individual expatriate experiences to understand diplomacy also illustrates how, at the time, it struggled with 
ethnocentrism and even racism in foreign affairs. This is highlighted in the I974 report when government officials assessed the success of expatriates in the Pacific through narratives of intermarriage. For example, the deputy minister explained that "we don't have racial prejudices, so we can interact harmoniously with the local people," after which he approvingly told the story of Wong Kee, an expatriate who married the daughter of a local chief in Sāmoa (LYG I975, 8). Yet he also narrated the tale of an expatriate in Papua New Guinea that reads as both ethnocentric and racist:

[Mr Chen] took a local aboriginal as his wife and they had a son with curly hair and black skin... Mr Chen has forbidden his children to speak to the aborigines using aboriginal languages and has taught them using Cantonese. When he was on his deathbed, he told his son that he must take a Chinese woman as his wife, and his son did marry [such] a woman. They already have two sons whose skin is of a Chinese tone. They are truly patriotic. (LYG I975, II)

Notably, just as Tuvaluan newspaper articles on interactions with Taiwan are mediated not through government-to-government interactions but rather through trans-local engagements at the government-to-individual or government-to-group level, the Taiwan government's earliest mission to the Pacific is also mediated through government-to-individual interactions. This is because imaginings of Pacific relations are continuously articulated to the experiences of individual Chinese or Taiwanese expatriates. Government discourse also demonstrates an ambivalence concerning how expatriates should comport themselves, specifically with regard to ethnicity and race, as tales of both integration into and assimilation of Pacific communities are proffered as examples of ideal behavior. Although this ambivalence may have been prompted by racial prejudice targeted against Pacific peoples with darker as opposed to lighter skin tones (LYG I975, 7), it also illustrates uncertainty regarding whether Taiwan should position itself as superior or equal to Pacific nations. This uncertainty is apparent in official discourse even today.

Although the 1974 report is rich with narratives from Taiwan's first mission to the Pacific, Tuvalu is not specifically mentioned until a second record from I988, when the Taiwan ambassador to Tonga and Tuvalu spoke before the Taiwan Legislature. By I988, a more pragmatic, formalized tone characterized reporting, and Tuvalu and Tonga were discussed vis-à-vis PRC encroachment, strategic positioning, and the necessity for Taiwan to compete with Australia, New Zealand, Japan, and Europe in 
providing Pacific aid (LYG I989, 28 I-284, 286-287). This signals movement from the disparate and individually based elements of Pacific diplomacy apparent in 1974 toward a cohesive vision regarding which issues should constitute Pacific-Taiwan relations.

However, an exchange between the ambassador and Taiwanese legislators regarding aid to Tuvalu reveals how, even in I988, Taiwan's diplomatic discourse was still highly fragmented. During this exchange, the ambassador described a conversation with Tuvalu's prime minister, Dr Tomasi Puapua, in which the prime minister requested Taiwan's financial support for hotel construction. The ambassador explained that because Puapua was a doctor and "different from your average slippery politician," it would be best to promptly provide funding so as to "[aid] the election of the ... prime minister to another term" (LYG I989, 284). This suggestion was met with strident criticism from Taiwanese legislators, but the varied perspectives reflected in their criticisms demonstrate disparate understandings of diplomacy with Tuvalu and the Pacific at large. One legislator, viewing Taiwan as a "great and impressive nation," exclaimed that Taiwanese diplomats need not kowtow to allies simply out of fear they would sever relations (LYG I989, 285). Another criticized the ambassador for not being a "modern diplomat" who would understand that he must "not interfere in the domestic politics of other countries" and that swaying an election would be "a scandal among democratic nations" (LYG I989, 286-287). Yet another legislator suggested that links between Taiwan's indigenous peoples and Pacific nations should be used to "promote Taiwan's diplomatic work," noting the need to examine claims that "Polynesians [originated] from the Asian mainland" (LYG I989, 288).

Here, divergent conceptualizations articulate to Taiwan's diplomacy in Tuvalu and the wider Pacific. These conceptualizations include continued belief in Taiwan as the true seat of the Chinese government and a powerful nation that must conduct itself as such in diplomacy, neoliberal conceptions of Taiwan as needing to exemplify a modern and democratic stance in international relations, and connections linking Taiwan's indigenous peoples to Pacific diplomacy. These ideas reveal multiple perspectives on what Taiwan's national identity is and how it might best be expressed in the Pacific.

In fact, although tales of individual or small-group interactions characterized discourse at the beginnings of Tuvalu-Taiwan allied relations, today, diplomatic discourse is more clearly fixated on considerations of identity. While early narratives mark the trans-local and fragmented 
nature of relations, more recent accounts demonstrate how discourse on diplomacy is now a means of representing self through other, or, more specifically, of reinforcing national identity by defining how Tuvalu and Taiwan exist in relation to each other.

\section{Identifying Self in Tuvalu-Taiwan Relations- 2000 TO THE PREsent}

After the uncertain beginnings of Tuvalu-Taiwan relations-as understood through narratives of rogue Taiwanese fishing vessels in Tuvalu News Sheet and Chinese or Taiwanese expatriates in Taiwan-government reports-discourse on more recent diplomatic relations, especially that found in leadership statements from 2000 to the present, has disarticulated from trans-local explications. Now, it focuses on totalizing rhetoric in which each nation defines the other as a unified whole that reflects and refracts its own identity. However, contemporary discourse on TuvaluTaiwan relations also clearly demonstrates articulation on two levels. First, this discourse is still connected to narratives from the r97os and I980s. Second, in this discourse, Tuvalu and Taiwan continue to maintain complex imaginings of each other in which elements are articulated to or disarticulated from rhetoric based on changing domestic and international circumstances and to achieve varied objectives. Consequently, in the following two subsections, I outline how Tuvalu and Taiwan have identified self and other in more recent official discourse while simultaneously highlighting the articulation inherent in this process and connections to earlier narratives.

\section{Tuvalu: Taiwan as Enemy, Cause, Family}

From 2000, when Tuvalu joined the United Nations, to the present, Taiwan has surfaced in various statements from high-level Tuvaluan government officials and been multiply articulated to discourses of enmity, moral cause, and kinship, demonstrating Tuvalu's complex regional, international, and bilateral identities and how Tuvalu uses Taiwan to rhetorically fortify these identifications.

First, in Tuvalu's regional fisheries statements, Taiwan has been articulated to discourses of enmity and become symbolic of Pacific Rim powers attempting to wrest fishing rights from Tuvalu and the broader Pacific region. I outline this discourse first because it links to earlier TNS narratives of tracking and detaining Taiwanese fishing vessels. For example, 
at the twelfth Western and Central Pacific Fisheries Commission meeting in 2015, Elisala Pita, Tuvalu's minister for natural resources at the time, commented:

Until just a few weeks ago the construction of our second vessel continued to be blocked by certain Commission members. ... I would stress ... that the recent unblocking of this process was not because these [Commission Members, Cooperating Non-Members, and Participating Territories (CCMs)] suddenly decided to respect and abide by the measures of this Commission. It was because, at the request of Tuvalu, [the Parties to the Nauru Agreement (PNA)] threatened to prohibit fishing in PNA waters by vessels of the CCMs concerned. ... I hope you will remember that this fishery takes place primarily in the Pacific Islands, and must be managed in a way that provides benefits to the people of that region. $(2015 \mathrm{~b}, 3)^{4}$

Earlier that year, the nations with which Pita took issue had been identified as Japan and, most specifically, Taiwan (RNZ 20I5). Thus, in the I970s and I980s, Taiwanese ships in Tuvalu waters unified the islands of Tuvalu (and even Fiji) in joint pursuit, and, in more recent discourse, Taiwan and its fisheries violations unite the Pacific region (or at least the PNA) in cooperative action. Here, Taiwan serves as a symbolic outsider demarcating national Tuvaluan and regional Pacific interests.

Yet outside of fisheries meetings, and most visibly at the United Nations, Tuvalu's discourse on Taiwan disarticulates from a history of fisheries disputes. Instead, Taiwan is a moral cause through which Tuvalu gains affective leverage by championing a nation that has been shunned in the UN structure. Karen McNamara noted that in UN climate-change negotiations, Pacific nations control "considerable moral leverage" $(2009,8)$, and Tuvalu's UN discourse on Taiwan is positioned to achieve a similar effect. ${ }^{5}$ For example, in 2002, then Governor General Sir Tomasi Puapua expressed Tuvalu's hope, "as a peace-loving nation," that "the right to self-determination of the people of the Republic of China and [their right] to join the United Nations [would] be urgently addressed." If the United Nations did not ameliorate this issue, he added, it could not be seen as "universal" nor could it fulfill its charter to maintain "peace and security for all nations of the world" (UNGA 2002, 2). Ten years later, in 20II, then Prime Minister Willy Telavi similarly intoned that "collective efforts to strengthen and maintain peace across the globe [would] be meaningless, if the United Nations [continued] to turn blind eyes and deaf ears to Taiwan's contribution" (UNGA 20I I, I 5). For Tuvalu, at the internationally 
oriented United Nations, Taiwan is no longer a tool for building Pacific regional unity through discourse on fisheries transgressions; rather, it is used to identify Tuvalu as a moral actor on the world stage and is articulated to a humanitarian cause that distinguishes Tuvalu, along with Taiwan's sixteen other allies, among the United Nations' numerous member states.

Finally, in Tuvalu's bilateral leadership discourse, Taiwan is further disarticulated from themes of enmity and morality and even the concept of the nation-state itself. Here, Tuvalu rearticulates itself and its ally into a sweeping history in which Taiwan is neither an egregious intruder demarcating the insiders of Tuvalu and the wider Pacific nor a pitiable outsider denied admission to the United Nations but, instead, the ancestral home of Tuvalu and Polynesia. Thus, at the 2013 opening of the Tuvalu embassy in Taiwan, then Prime Minister Telavi explained:

Tuvalu is the oldest ally for Taiwan in the Pacific region. But our ties are much older than this. Studies of the origins of the Polynesian languages of the Pacific, including Tuvaluan, suggest that they are strongly linked to the Indigenous Peoples of Taiwan. This connection extends back over 5,000 years. So in a way, the establishment of this Embassy is a symbolic homecoming for us. (Telavi 20I3, 2)

Although prompted by diplomatic considerations, Telavi's articulation of Taiwan to a regional imagining that predates contemporary diplomacy unsettles national boundaries increasingly evident in Tuvaluan discourse from the I970s to the present. It also highlights how early reports and more recent statements on Taiwan in Tuvalu indicate new perspectives on the Tuvalu-Taiwan relationship, illuminating broad historical and geographic ties often missing from analysis of Pacific-Asia diplomacy (Salesa 201 2, 400-402).

\section{Taiwan: Tuvalu as Signifier of Oceanic Taiwan or Donor Taiwan}

Digital records of Taiwanese leadership statements on Tuvalu are available beginning from 1992, which was during the presidency of Lee Teng-hui, who later became Taiwan's first democratically elected president in I996. ${ }^{6}$ However, these statements are brief and were typically published in the form of press releases. Given this, I focus on leadership statements spanning the presidential terms of Taiwan's second and third directly elected presidents: Chen Shui-bian (2000-2008), who represented the Democratic Progressive Party (DPP) and its movement toward Taiwan- 
ese independence, and Ma Ying-jeou (2008-20I6), who fronted the more PRC-friendly кмт Party. ${ }^{7}$ In these bodies of discourse, Tuvalu has been articulated to sometimes radically different ideas. However, these leadership statements all reflect official attempts to define Taiwan through its conduct of diplomacy with Tuvalu, as well as ambivalent ethnocentrism regarding Taiwan's superiority to the Pacific, which is similar to rhetoric from the I970s and I980s. ${ }^{8}$

Chen Shui-bian's ascension to the presidency in 2000 represented the first peaceful transition of power in Taiwan. Although relations between Taiwan and the PRC were hardly peaceful during and directly after the KMT-controlled martial law period (I949-I987), the election of a DPP president was not a welcome change to the PRC, and wrestling over diplomatic allies and Taiwan's sovereign status was characteristic of Chen's presidency (Yang 20I I, 56-59, 68). During this period, Taiwanese leadership statements demonstrate a consistent pattern of formulating a common identity for Tuvalu, the Pacific, and Taiwan so as to suggest a Taiwanese identity and national status independent from the PRC. Here, Chen adopted affective rhetoric that highlighted Austronesian linguistic ties between indigenous peoples in Taiwan and the Pacific, which recalls certain recommendations outlined in the 1988 Taiwan Legislature report discussed in the previous section.

A common theme in official Taiwanese discourse on Tuvalu is the presumed need to continually define Tuvalu and make it "knowable" before undertaking further discussion on Tuvalu-Taiwan relations. As posited by Chen, Tuvalu is small, possesses abundant marine resources, and is righteous or peaceful (see Office of the President, Republic of China [Taiwan] 2002). The first two characteristics appear in other leadership descriptions of Tuvalu, but the last is specifically highlighted by Chen and is indicative of the common identity he hoped to create for Tuvalu, the Pacific, and Taiwan, which was predicated on constructing Tuvalu and other Pacific allies as worthy of this shared identity. Consequently, in his typically effusive fashion, Chen explained:

Tuvalu is the most peaceful country in the world and its people are [also] the most peaceful [in the world]... . The whole world should learn from the people of Tuvalu. If they did, there would be no war and world peace would be eternal. (Office of the President, Republic of China [Taiwan] 2005)

This definition of Tuvalu furthers Chen's goal of then articulating Taiwan to Tuvalu and the Pacific through mutual ocean or island-nation 
identities and utilizing Taiwan's position as the purported origin of the Austronesian language group, which includes Pacific languages, to further bolster a united status (Mona 2007). Here, Chen's strategy is similar to that adopted by Telavi at the opening ceremony for the Tuvalu embassy in Taiwan. However, Chen's discourse is not aimed merely at creating bilateral goodwill but also at articulating Taiwan into a Pacific regional vision that redefines Taiwan internationally. To this point, Chen explained that "the foundation for strong [Tuvalu-Taiwan] friendships" was the shared status of "Tuvaluans and Taiwanese [as] ocean peoples" (Office of the President, Republic of China [Taiwan] 2002). Chen further declared:

The Pacific Ocean ... nurtured the Austronesian culture ... as well as the precious and mutually supportive friendship between Taiwan and its Pacific allies. The vast Pacific Ocean has not created a barrier between us and has instead provided plentiful resources and become an ocean that we all depend on for survival. In the spirit of brotherhood and mutual trust and benefit, let us work diligently toward the creation of a better Pacific era. (Office of the President, Republic of China [Taiwan] 2006b)

Although Chen was not above patronizing Tuvalu and Taiwan's other Pacific allies (see Office of the President, Republic of China [Taiwan] 2006a), his discursive strategies demonstrate attempts not to articulate Tuvalu and the Pacific to any specific ideas but rather to articulate Taiwan to Tuvalu and the Pacific so as to re-form Taiwan's domestic, regional, and international position. Tuvalu moves in broad regional and international circles that allow it to connect Taiwan to multiple identities to achieve varied ends. By contrast, Taiwan's more circumscribed global standing necessitates not the articulation of Tuvalu into multiple contexts but rather the articulation of Taiwan to Tuvalu and the Pacific to construct new possibilities for national identification.

After Taiwan's 2008 presidential election, the KMT Party regained power under President Ma Ying-jeou. Ma's foreign policy was radically different from Chen's; it was predicated on constructing a diplomatic truce with the PRC and positioning Taiwan as supportive of Pacific development programs championed by traditional donors like Australia (Overton 20I6; Yang 20II, 7I). Thus, in contrast to Chen's construction of a common Tuvalu- or Pacific-Taiwan identity, Ma developed separate but mutually constitutive identities for Tuvalu/the Pacific and Taiwan in which Taiwan was articulated to a respectable consortium of donor countries that dealt peaceably with the PRC: 
Our viable diplomacy can allow us to win friendship and respect from our allies and gradually change our relations with mainland China.... From the perspective of international society, and especially in the South Pacific region, Australia has shown great admiration for us. This is a tremendous difference from three years ago when they would frequently criticize us. We have created a climate in which international society, Taiwan, and mainland China all win. (Office of the President, Republic of China [Taiwan] 20Ioa)

In this discourse, Tuvalu is articulated into a group of so-called developing countries who offer certain advantages to Taiwan but also require Taiwan's humanitarian assistance (Office of the President, Republic of China [Taiwan] 20Iob). Taiwan's Pacific allies are thus conceptually reimagined:

The difference between these six [Pacific] allies and [our] other allies is that they only became independent after $1979[$ sic]. Furthermore, aside from Solomon Islands, ... a characteristic [of the Pacific allies] is that their populations are extremely small [and] their resources are relatively lacking. The countries are still developing or are even in a relatively low state of development. They therefore require aid from foreign countries or international society. As a nation in which average income is US\$I 6,000 , the ROC has a duty to provide aid. Additionally, although these [Pacific] countries are small, they still have a vote in international organizations. (Office of the President, Republic of China [Taiwan] 20IOc)

Similar to Chen, Ma used Tuvalu and Taiwan's other Pacific allies to define Taiwan. However, in contrast to Chen, Ma's discursive strategy is more aligned with discourse from the previously mentioned I988 Taiwan Legislature report in which Taiwan was understood not in terms of Austronesian connections to Tuvalu but in terms of how an important, modern, and democratic nation should conduct international diplomacy.

As illustrated by $\mathrm{Ma}$ and Chen, recent Taiwanese leadership statements on Tuvalu evince striking disparities, which, like Tuvaluan discourse, show the fragmented and articulated nature of diplomatic alliances, especially as the discursive use of these alliances effects continuous and changing interpretations of their significance (Wood and Kroger 2000, IO-I2). Also notable is how fragmented elements from this discourse connect back to government reports from 1974 and I988. For example, different ideas of the Tuvalu-Taiwan relationship as explicated in the I988 Taiwan Legislature report surface in Chen and Ma's divergent imaginings of how Pacific diplomacy should be conducted. Furthermore, given the ambivalent ethnocentrism and racism found in the 1974 report, it is interesting 
to consider the variance in how Chen and Ma used Tuvalu and other Pacific allies to build a national identity for Taiwan. While Chen discursively bypassed ethnocentrism by imagining the possibility for one Pacific people, Ma rejected this conceptualization, seeing Taiwan as a beneficent donor separate from and above its Pacific allies.

\section{Conclusion: Articulating Diplomatic Relations Past and Present}

The goals of articulation theory and discourse analysis are extraordinarily similar: Articulation illuminates contexts and demonstrates how conjoined fragments "might be re-articulated" to "[shape] intervention within a particular social formation" (Slack 1996, I I2, I23), while discourse analysis "[contributes] to change in the way that people talk ... [initiating] a change in practice" (Wood and Kroger 2000, I3). This political potential makes articulation and discourse analysis critical to Pacific studies and its work toward "empowerment for mutual exchange" (T Teaiwa 20I0, I I7). This is because it promotes critical understandings of how things came to be, how they might be undone, and how "[they] could be done differently" (Wood and Kroger 2000, I4; see also T Teaiwa 2005).

My goal in analyzing Tuvaluan and Taiwanese discourse has not been to "shape intervention" or effect "a change in practice" regarding how this discourse is constructed. Instead, I hope to motivate change in the ways this discourse is analyzed or even to advocate that this discourse be more seriously considered in writing on Tuvalu-Taiwan, Pacific-Taiwan-PRC, and Pacific-Asia diplomacy. As Teresia Teaiwa cogently noted, scholarly attempts to answer questions "must account for specificities of nationality, culture, and history," and, "quite simply, context matters" (20I5, I). I began my discussion by illustrating both the varied contexts constituting Tuvalu and Taiwan when they established diplomatic ties and how the Tuvalu-Taiwan relationship was imagined when Tuvalu and Taiwan encountered each other as national entities in the wake of Tuvalu's independence. In doing so, I showed that, despite the teleological fashion in which analysts might now imagine Taiwan-PRC competition in the Pacific, not forty years ago, discourse and relationships were uncertain, contingent, and defined by "multiple sites of trans-localism ... tied to histories dependent on the ocean" (Matsuda 20I 2, 5). By including discourse from the beginnings of Tuvalu-Taiwan relations, I further offset trends in current international-politics research that occlude local and contingent 
connections in the Pacific-Asia region (Salesa 20I6), thereby indicating complex networks that preceded, prompted, and continue to affect diplomatic relationships as we understand them today.

For both Tuvalu and Taiwan, early attempts at building governmentto-government ties were anchored in government-to-individual or government-to-group experiences that defined how higher-level relationships might proceed or that highlighted the necessity of forming official relationships at a specific moment. This demonstrates how Pacific trans-localism contributed to the formation of diplomatic ties. Furthermore, although this early discourse cannot be consistently linked to more recent leadership statements, it does suggest general confluences over time. That is, Taiwan is regularly tied to Tuvalu's fisheries concerns and its concomitant mobilization of regional networks, while Tuvalu is consistently connected to Taiwan's ambivalence regarding its proper international role and superiority vis-à-vis the Pacific.

In sum, this article illustrates how shifting discursive articulations characterize diplomatic relations and shows that processes of articulating and disarticulating are equally apparent in Taiwanese and Tuvaluan discourse. This analysis is thus particularly important because it recognizes the discursive agency of both Taiwan and Tuvalu. However, it is also critical in calling attention to how Taiwan is only one part of Tuvalu's local, national, regional, and international imaginings, a reality often overlooked in analysis of Pacific-Taiwan-PRC diplomacy. This recognition moves against totalizing "[assumptions] of unequal power relations" and underscores Tuvalu's agentic rather than instrumentalized role in diplomacy past and present (K Teaiwa 2007, 3-4).

THis RESEARCH WAS PARTIALLY SUPPORTED by a grant from the Center for Chinese Studies in Taipei, Taiwan. Thanks also to two anonymous reviewers for their insightful comments.

\section{Notes}

I Teresia Teaiwa later recommended a critical empowerment rationale, in which "Pacific studies students [and scholars] . . critically evaluate all forms and sources of power, including indigenous ones, and indeed, their own" (20I7 b, 269). 
2 In the I970s and I980s, the Taiwan government and many expatriates saw Taiwan as the seat of the Chinese government. Consequently, expatriates from Taiwan and mainland China are emphasized in 1974 reporting (Chiang I982, 55-56, I987, I39; Sun 1980, I23).

3 See also Australia-Free China Society 1975; Chiang I98I.

4 For further fisheries statements, see Boreham 2016; Pita 201 5 a. For a positive regional statement on Taiwan, see Sopoaga 2016.

5 Although Tuvalu's UN discourse on Taiwan may be prompted by the Taiwan government, Taiwan's allies have always exerted agency in deciding whether to defend Taiwan at the United Nations (Fu 2007; UDN I995).

6 During martial law (I949-I987) and until I996, presidents were elected by Taiwan's National Assembly (Wang 2013, 82-83).

7 Because Tuvalu does not have political parties, I do not address party ideologies in the section on Tuvaluan leadership statements.

8 The discourse of Taiwan's current president, Tsai Ing-wen, is not considered here because her term only began in May 2016. However, based on Tsai's statements thus far, she takes a middle path between Chen and Ma. She emphasizes a common identity for Tuvalu, the Pacific, and Taiwan and the need to collectively attain sustainable development, but she also uses Taiwan's aid projects in Tuvalu and the Pacific to identify Taiwan as making useful contributions to the global community (see Office of the President, Republic of China [Taiwan] 20I7a, 20I7b).

\section{References}

Aqorau, Transform

2015 How Tuna is Shaping Regional Diplomacy. In The New Pacific Diplomacy, edited by Greg Fry and Sandra Tarte, 223-235. Acton, ACT: ANu Press.

Australia-Free China Society

I975 Correspondence regarding Taiwanese fishing arrests in Australia. 5 August. Institute of Modern History Archives, O20-OI I 504-OOI 8. Taipei: Academia Sinica.

Beaulieu, Marc

2009 Tuvaluan Faatele: A Performative and Historico-Geographic Context. Context: Journal of Music Research 34:49-64.

Boreham, Puakena

2016 Tuvalu Opening Statement by Tuvalu Minister for Natural Resources Puakena Boreham. Given at the I 3 th Regular Session of the Western and Central Pacific Fisheries Commission (WCPFC), Nadi, Fiji, 5-9 December. https://www.ffa.int/node/I 83 I [accessed I4 Nov 20I8] 
Chiang, Ching-kuo

I98 I Minguo qishinian shiyiyue zongtong jiangjingguo jieshou tuwalu xinren zhuhua dashi aiwonatana chengdi daoren guoshu tanhua jilu [Record of presentation of credentials by new Tuvalu Ambassador to Taiwan Ionatana to President Chiang Ching-kuo in November I98I]. 6 November. Records for Foreign Guests Chiang Ching-kuo Met in I98 I (3), or 8. President Chiang Ching-kuo Collection, o05о10303-00008-018. Taipei: Academia Historica.

I982 Jiangzongtong jingguo xiansheng qishinian yanlunji [I98 I speeches by President Chiang Ching-kuo]. Taipei: Government Information Office.

I987 Jiangzongtong jingguo xiansheng qishiwunian yanlunji [I986 speeches by President Chiang Ching-kuo]. Taipei: Government Information Office.

Chu, Huei-chu

2015 Islands as the Origin/End of the World: Ethnographic Imaginations from the Penghu (Taiwan) and Yaeyama (Okinawa) Islands. Comparative Literature Studies 52 (4): 704-728.

Clifford, James

2003 On the Edges of Anthropology (Interviews). Chicago: Prickly Paradigm Press.

Corcuff, Stéphane

2000 Taiwan's “Mainlanders”: A New Ethnic Category. China Perspectives 28:7 I-8I.

D'Arcy, Paul

2016 The Chinese Pacific: An Historical Review. In China and the Pacific:

The View from Oceania, edited by Michael Powles, 46-52. Wellington: Victoria University Press.

Dvorak, Greg

20I4 Who Closed the Sea? Archipelagoes of Amnesia between the United States and Japan. Pacific Historical Review 83 (2): 350-372.

$\mathrm{Fu}$, Yijie

2007 Rulian fan'an shibai, lianda shezhan yu 4 xiaoshi [Reversal on UN admission decision fails: Debate at UN General Assembly lasts over 4 hours]. United Daily News, 23 September.

Gao, Huiyu

I980 Zuigao de zhihui, zuiqiang de tuanjie, zuida de xinxin, yingjie zhanxin de bashi niandai, yi zuigao de zhihui he xinxin dakai waijiao xinju [Welcoming the I980s with the greatest wisdom, strongest unions, and greatest confidence: Beginning a new period in diplomacy with the greatest wisdom and confidence]. United Daily News, I January. 
Goldsmith, Michael

2012 The Colonial and Postcolonial Roots of Ethnonationalism in Tuvalu. The Journal of the Polynesian Society I I (2): I 29-I 50.

20I6 Bibliography of Tuvalu. Hamilton, NZ: M Goldsmith.

Goss, Jon, and Terence Wesley-Smith

2010 Introduction: Remaking Area Studies. In Remaking Area Studies: Teaching and Learning across Asia and the Pacific, edited by Terence Wesley-Smith and Jon Goss, ix-xxvii. Honolulu: University of Hawai'i Press.

Hajer, Maarten, and Wytske Versteeg

2005 A Decade of Discourse Analysis of Environmental Politics: Achievements, Challenges, Perspectives. Journal of Environmental Policy \& Planning 7 (3): I75-I 84 .

Heylen, Ann

2010 The Transnational in Taiwan History: A Preliminary Exploration.

Concentric: Literary and Cultural Studies 36 (I): 9-33.

$\mathrm{Hu}$, Shaohua

2015 Small State Foreign Policy: The Diplomatic Recognition of Taiwan.

Izumi, Kobayashi

China: An International Journal I3 (2): I-23.

2010 China's Advances in Oceania and Japan's Response. In China in Oceania: Reshaping the Pacific?, edited by Terence Wesley-Smith and Edgar A Porter, 85-92. New York: Berghahn Books.

Lawson, Mary Elizabeth

I989 Tradition, Change and Meaning in Kiribati Performance: An Ethnography of Music and Dance in a Micronesian Society. PhD dissertation, Brown University.

LYG, Legislative Yuan Gazette

I975 Waijiaobu yangxikun cizhang baogao fangwen nantaipingyang zhi jingguo [Ministry of Foreign Affairs Deputy Minister Yang Hsi-kun reports on visit to the South Pacific]. 64 (6): 5-I3.

I989 Zhu dongjia wangguo dashi qianaiqian bagao "woguo yu dongjia wangguo zhi waijiao guanxi ji nantaipingyang qingshi” [Resident Ambassador to the Kingdom of Tonga Clement A.K. Tsien reports on "the diplomatic relationship between Taiwan and the Kingdom of Tonga and circumstances in the South Pacific"]. 78 (44): 28 I-289.

Matsuda, Matt K

2012 Pacific Worlds: A History of Seas, Peoples, and Cultures. Cambridge, UK: Cambridge University Press.

McNamara, Karen E

2009 Voices from the Margins: Pacific Ambassadors and the Geopolitics of Marginality at the United Nations. Asia Pacific Viewpoint 50 (I): I-I 2 . 
Mona, Awi

2007 Taiwan de nandao minzu waijiao [Taiwan's Austronesian foreign affairs]. Taiwan International Studies Quarterly 3 (3): I6I-I 86.

Muyard, Frank

2015 Comparativism and Taiwan Studies: Analyzing Taiwan in/out of Context, or Taiwan as an East Asian New World Society. In Comparatizing Taiwan, edited by Shu-mei Shih and Ping-hui Liao, I3-32. New York: Routledge.

Noricks, Jay Smith

I98I Niutao Kinship and Social Organization. PhD dissertation, University of Pennsylvania.

Office of the President, Republic of China (Taiwan)

2002 Zongtong jiejian tuwalu zongli taolekai [President receives Tuvalu's Prime Minister Talake]. I 8 April. http://www.president.gov.tw/ NEWS/I 557 [accessed I4 Nov 2018]

2005 Zongtong fangwen tuwalu bing guojing feiji [President visits Tuvalu and transits through Fiji]. 4 May. http://www.president.gov.tw/ NEWS/94 I 2 [accessed I4 Nov 2018]

2006a Zongtong fangwen boliu diyitian xingcheng [Itinerary for the president's first day in Palau]. 3 September. https://www.president.gov.tw/ NEWS/ı068I [accessed I 4 Nov 20I8]

2006b Zongtong chuxi diyijie taiwan yu taipingyang youbang yuanshou gaofeng huiyi [President attends the First Taiwan-Pacific Allies Summit]. 4 September. http://www.president.gov.tw/NEWS/I0682 [accessed I 4 Nov 20I8]

20I0a Zongtong qicheng fangwen nantaipingyang youbang [President departs for visit to South Pacific allies]. 2I March. http://www .president.gov.tw/NEWS/I4I69 [accessed I4 Nov 20I8]

20Iob Zongtong dida tuwalu [President arrives in Tuvalu]. 23 March. http://www.president.gov.tw/NEWS/I4I75 [accessed I4 Nov 20I8]

20I0c Zongtong fanguo yu jichang tanhua [President returns, speaks at airport]. 27 March. http://www.president.gov.tw/NEWS/I4I89 [accessed I 4 Nov 20I8]

20I7a Zongtong jiejian tuwaluguo guohui yizhang taoxi kangli fangwentuan [President Tsai meets Tuvalu Parliamentary Speaker Otinielu Tauteleimalae Tausi]. I4 July. http://www.president.gov.tw/NEWS/ 2I49I [accessed I4 Nov 20I8]

20I7b Zongtong fabiao “'yongxu nandao, xieshou gonghao' 20I7 taipingyang youbang zhilv" fanguo tanhua [President Tsai returns to Taiwan and addresses the press]. 4 November. http://www.president .gov.tw/NEWS/2 I 768 [accessed I4 Nov 20I8]

Overton, John

2016 The Context of Overall Aid in the Pacific-and Its Effectiveness. In 
China and the Pacific: The View from Oceania, edited by Michael Powles, I6I-I72. Wellington: Victoria University Press.

Pita, Elisala

20I 5 a Address to the 46th Pacific Islands Forum Leaders' Meeting by the Hon. Elisala Pita, Tuvalu Minister of Natural Resources (Fisheries), Chair of the Ministerial Forum Fisheries Committee. Given at the 46th Pacific Islands Forum, Port Moresby, Papua New Guinea, September. https://www.ffa.int/node/I 559 [accessed I4 Nov 20I8]

20I5b Tuvalu Opening Statement for WCPFCi2. I 2th Regular Session of the wCPFC, Bali, Indonesia, 3 December. Available from https:// www.wcpfc.int/node/27I 26 [accessed I4 Nov 20I 8]

RNZ, Radio New Zealand

2015 Tuvalu Irked by Big Power Fishing Stance. I 2 June. http://www .radionz.co.nz/international/pacific-news/276096/tuvalu-irked-by -big-power-fishing-stance [accessed I 4 Nov 20I8]

Salesa, Damon

2012 The World from Oceania. In A Companion to World History, edited by Douglas Northrop, 39I-404. Chichester, UK: Wiley-Blackwell.

2016 Chinese-Samoan Interactions-Influences Both Ways: Entangled and Intimate Histories. In China and the Pacific: The View from Oceania, edited by Michael Powles, I23-I27. Wellington: Victoria University Press.

Shih, Shu-mei

20II The Concept of the Sinophone. PMLA I 26 (3): 709-7I 8.

2016 Lilun taiwan chulun [A preliminary discussion of theory Taiwan]. In Zhishi taiwan: Taiwan lilun de kenengxing [Knowledge/Taiwan: The possibility of Taiwan theory], edited by Shu-mei Shih, Chia-ling Mei, Chao-yang Liao, and Dung-Sheng Chen, 55-94. Taipei: Rye Field Publications.

Slack, Jennifer Daryl

I996 The Theory and Method of Articulation in Cultural Studies. In Stuart Hall: Critical Dialogues in Cultural Studies, edited by David Morley and Kuan-Hsing Chen, I I 2-I 27. New York: Routledge.

Smith, Graeme

2012 Chinese Reactions to Anti-Asian Riots in the Pacific. The Journal of Pacific History 47 (I): 93-I09.

Sopoaga, Enele Sosene

2016 Tuvalu's Prime Minister, Honorable Enele Sopoaga's Remarks to the Regional Meeting on Climate Change and Migration Workshop. Given at the Regional Meeting on Climate Change and Migration in the Pacific, Suva, Fiji, 7 December. https://www.forumsec.org/tuvalus -prime-minister-honorable-enele-sopoagas-remarks-to-the-regional 
-meeting-on-climate-change-and-migration-workshop/ [accessed I4 Nov 20I 8]

Sun, Yun-suan

I980 Xingzhengyuan sunyuanzhang liushibanian yanlunji [I979 speeches by Executive Yuan President Sun Yun-suan]. Taipei: Government Information Office.

Teaiwa, Katerina Martina

2004 Multi-Sited Methodologies: "Homework" in Australia, Fiji, and Kiribati. In Anthropologists in the Field: Cases in Participant Observation, edited by Lynne Hume and Jane Mulcock, 216-233. New York: Columbia University Press.

2007 Indigenous Encounters: Reflections on Relations between People in the Pacific. In Indigenous Encounters: Reflections on Relations between People in the Pacific, edited by Katerina Martina Teaiwa, I-9. Occasional Paper Series 43. Honolulu: Center for Pacific Islands Studies, School of Hawaiian, Asian, and Pacific Studies, University of Hawai'i at Mānoa.

2014 Reframing Oceania: Lessons from Pacific Studies. In Framing the Global: Entry Points for Research, edited by Hilary E Kahn, 67-96. Bloomington: Indiana University Press.

Teaiwa, Teresia K

$200 \mathrm{I} L$ L(o)osing the Edge. The Contemporary Pacific I3 (2): 343-357.

2005 Articulated Cultures: Militarism and Masculinities in Fiji during the Mid I990s. Fijian Studies: A Journal of Contemporary Fiji 3 (2): 2OI-222.

2010 For or Before an Asia Pacific Studies Agenda? Specifying Pacific Studies. In Remaking Area Studies: Teaching and Learning across Asia and the Pacific, edited by Terence Wesley-Smith and Jon Goss, I IO-I 24. Honolulu: University of Hawai'i Press.

2OI 5 What Makes Fiji Women Soldiers? Context, Context, Context. Intersections: Gender and Sexuality in Asia and the Pacific 37. http:// intersections.anu.edu.au/issue37/teaiwa.htm [accessed I9 March 2019]

20I7a The Articulated Limb: Theorizing Indigenous Pacific Participation in the Military Industrial Complex. Pacific Dynamics: Journal of Interdisciplinary Research I (I): I-20.

20I7b Charting Pacific (Studies) Waters: Evidence of Teaching and Learning. The Contemporary Pacific 29 (2): 265-282.

Telavi, Willy

20I3 Statement by the Prime Minister of Tuvalu Honourable Willy Telavi at the Opening Ceremony of the Embassy of Tuvalu in the Republic of China (Taiwan). Taipei, I 4 March. https://static .squarespace 
.com/static/53089893e4bo9ao7 I 6b753ae/t/53ca7b64e4bo76d $747 \mathrm{f}$ $8 \mathrm{f}_{5} \mathrm{~d} 6 / \mathrm{I}_{4} 057787885$ 20/20 I $3+03$ I 4 th $+\mathrm{PM}+$ Speech + for + Opening Topo, James +of+Tuvalu+Embassy+in+Taiwan.pdf [accessed I 4 Nov 20I8]

20I4 Chinese Investment in Papua New Guinea: A Stimulus for Growth? In Pacific-Asia Partnerships in Resource Development, edited by Paul D'Arcy, Patrick Matbob, and Linda Crowl, 52-58. Madang: Divine Word University Press.

\section{Tuvalu Echoes}

I986a Republic of China and Tuvalu Renew Fisheries Licensing Agreement. 23 October.

I986b PM Addresses Nation. 6 November.

TNS, Tuvalu News Sheet

I978 Korean Diplomat Leaves: Negotiation Successful. 24 November.

r979a Tuvalu’s Asian Diplomacy. I6 March.

I979b Tuvalu Establishes Further Diplomatic Ties. I I May.

I979c Korea Ambassador Presents Credentials. 8 June.

r979d Taiwan Fishing Vessel Ordered to Pay \$20,000 Fine. 3 August.

I979e Government Issues Warning. 3 I August.

I979f Diplomats Present Letters of Introduction. I 2 December.

I980a Drama on the High Seas-Taiwanese Boat Escapes. 23 January.

I980b Repatriation Ends-All Home and Safe. 20 February. UDN, United Daily News

I979 Woguo yu tuwalu jianjiao, gaozheng jian tuwalu dashi [Taiwan and Tuvalu establish diplomatic relations, Gao Zheng becomes ambassador to Tuvalu]. 20 September.

I986 Tuwalu zongli jin dihua fangwen [Tuvalu prime minister arrives in ROC today]. 2I September.

I995 Qianqichen huijian hongdulasi fuzongtong, xiwang shuangfang zai lianheguonei hezuo, beijing shifuhui, zhonggong lalong yu wo bangjiaoguo [Qian Qichen meets with Honduras vice president, hopes for bilateral cooperation at the UN: Beijing World Conference on Women, PRC entices Taiwan's allies]. 6 September.

UNGA, United Nations General Assembly

2002 Official Records: 57th Session, 7th Plenary Meeting. New York, I4 September.

20II Official Records: 66th Session, 22nd Plenary Meeting. New York, 24 September.

Wang, Fu-chang

2013 Ethnic Politics and Democratic Transition in Taiwan. Oriental Institute Journal 22 (2): 8I-I07. 
Wesley-Smith, Terence

I995 Rethinking Pacific Islands Studies. Pacific Studies I 8 (2): I I 5-I 36.

2016 Rethinking Pacific Studies Twenty Years On. The Contemporary Pacific 28 (I): I 53-I69.

Wesley-Smith, Terence, and Edgar A Porter, editors

2010 China in Oceania: Reshaping the Pacific? New York: Berghahn Books.

Wood, Linda A, and Rolf O Kroger

2000 Doing Discourse Analysis: Methods for Studying Action in Talk and Text. Thousand Oaks, cA: Sage.

Yang, Jian

20I I The Pacific Islands in China's Grand Strategy: Small States, Big

Games. New York: Palgrave Macmillan.

\section{Abstract}

In March I979, Tuvalu's government newspaper began an ongoing discussion of Tuvalu's Asian diplomacy, highlighting the rapid development of relationships with East Asian nations like Taiwan shortly after Tuvalu's independence in I978. Contemporaneously, the Taiwan government began reporting on early diplomatic forays into Pacific nations, including Tuvalu. These newspaper and government reports are frequently characterized by a narrative style that suggests the complexities of Pacific-Asia relationships at the time and that provides a foundation from which more recent discourse on Tuvalu-Taiwan relations can be contextualized. In this paper, I adopt a Pacific studies rationale, articulation theory, and discourse analysis. I examine official Tuvaluan and Taiwanese narratives from the I970s and I980s to demonstrate how early diplomacy was determined not by official maneuvering but by preexisting trans-local connections. Subsequently, in analyzing Tuvaluan and Taiwanese leadership statements from 2000 to the present, I sketch how, more recently, Tuvalu and Taiwan have used each other to shape their national identities. However, I also highlight connections to earlier narratives, especially tension in Tuvaluan discourse due to fisheries conflicts with Taiwan and preoccupation in Taiwanese discourse regarding whether Taiwan is superior to Tuvalu. Finally, I demonstrate how articulations between early narratives and more recent discourse foreground Tuvaluan and Pacific agency and complicate assumed Asia-Pacific power hierarchies.

KEYWORDs: Tuvalu, Taiwan, diplomacy, official discourse, discourse analysis, articulation theory 